crystallized: $\mathrm{mp} 129^{\circ} \mathrm{C}$; IR $\left(\mathrm{CHCl}_{3}\right) 2970,1140 \mathrm{~cm}^{-1} ;{ }^{1} \mathrm{H}$ NMR $\left(\mathrm{CDCl}_{3}\right) \delta 4.10(2 \mathrm{H}, \mathrm{m}), 3.85(1 \mathrm{H}, \mathrm{s}), 2.6-0.6(11 \mathrm{H}$, complex $)$; mass spectrum, $m / e$ (relative intensity) 188/186 (11/36), 79 (100).

4-anti-Bromo-1-isopropyl-2-oxaadamantane (10). A 350-mg sample of la $(1.77 \mathrm{mmol})$ was treated with thionyl bromide as described for the synthesis of 8 . The yield was $118 \mathrm{mg}(26 \%)$ of 10 as a yellowish oil: IR $\left(\mathrm{CHCl}_{3}\right) 2950,1050 \mathrm{~cm}^{-1} ;{ }^{1} \mathrm{H}$ NMR $\left(\mathrm{CDCl}_{3}\right) \delta 4.55(1 \mathrm{H}, \mathrm{m}), 4.04(1 \mathrm{H}, \mathrm{m}), 2.6-1.1(11 \mathrm{H}$, complex $)$, $0.88(6 \mathrm{H}, \mathrm{d})$; mass spectrum, $m / e$ (relative intensity) $260 / 258$ $\left(15 / 16, \mathrm{M}^{+}\right), 217 / 215(7 / 7), 179(17), 174(51), 172(54), 123(70)$, $91(90), 43(100)$.

2-anti-Iodo-4,4-dimethyladamantane (23). A 185-mg sample of $1 \mathrm{a}(0.93 \mathrm{mmol})$ was refluxed overnight in $57 \%$ hydriodic acid. After cooling the reaction mixture was diluted with water and extracted with methylene chloride. After the usual workup, 149 $\mathrm{mg}(52 \%)$ of 23 as a colorless liquid was obtained which turned dark after some hours at room temperature: IR $\left(\mathrm{CHCl}_{3}\right) 2950$, $1460 \mathrm{~cm}^{-1} ;{ }_{1}^{1} \mathrm{H}$ NMR $\left(\mathrm{CDCl}_{3}\right) \delta 5.37(1 \mathrm{H}, \mathrm{m}), 2.5-1.2(12 \mathrm{H}$, complex), $1.10(6 \mathrm{H}, \mathrm{s}) ;{ }^{13} \mathrm{C}$ NMR $\left(\mathrm{CDCl}_{3}\right) \delta 47.0\left(\mathrm{C}^{3}\right), 44.6\left(\mathrm{C}^{2}\right)$, $39.0\left(\mathrm{C}^{4}\right), 37.4\left(\mathrm{C}^{1}\right), 36.7\left(\mathrm{C}^{5}\right), 34.9\left(\mathrm{C}^{8}\right), 34.7\left(\mathrm{C}^{9}\right), 34.1\left(\mathrm{C}^{6}\right), 28.8$ $\left(\mathrm{C}^{10}\right), 28.5\left(\mathrm{C}^{7}\right), 27.5\left(2 \mathrm{CH}_{3}\right)$; mass spectrum, $m / e$ (relative intensity) $163(100)\left(\mathrm{M}^{+}-\mathrm{I}\right)$.

2-anti-Bromo-4,4-dimethyladamantane. A 158-mg sample of $1 \mathrm{a}(0.81 \mathrm{mmol})$ was refluxed overnight in $48 \%$ hydrobromic acid. After cooling, the reaction mixture was diluted with water and extracted with methylene chloride. The usual workup afforded $33 \mathrm{mg} \mathrm{(16 \% )} \mathrm{of} \mathrm{2-anti-bromo-4,4-dimethyladamantane}$ as a colorless liquid: IR $\left(\mathrm{CHCl}_{3}\right) 2950,1460 \mathrm{~cm}^{-1} ;{ }^{1} \mathrm{H} \mathrm{NMR}$ $\left(\mathrm{CDCl}_{3}\right) \delta 5.12(1 \mathrm{H}, \mathrm{m}), 2.5-1.2(12 \mathrm{H}$, complex $), 1.10(6 \mathrm{H}, \mathrm{s})$; ${ }^{13} \mathrm{C} \mathrm{NMR}\left(\mathrm{CDCl}_{3}\right) \delta 61.7\left(\mathrm{C}^{2}\right), 45.7\left(\mathrm{C}^{3}\right), 38.9\left(\mathrm{C}^{4}\right), 36.4\left(\mathrm{C}^{5}\right), 36.1$
$\left(\mathrm{C}^{1}\right), 34.6\left(\mathrm{C}^{9}\right), 33.6\left(\mathrm{C}^{6}\right), 33.2\left(\mathrm{C}^{8}\right), 28.1\left(\mathrm{C}^{10}\right), 27.4\left(2 \mathrm{CH}_{3}\right), 27.1$ $\left(\mathrm{C}^{7}\right)$; mass spectrum, $m / e$ (relative intensity) $163(100)\left(\mathrm{M}^{+}-\mathrm{Br}\right)$.

Adamantane-2,4-dione (17). A 200-mg sample of 1c (1.10 mmol) were dissolved in $20 \mathrm{~mL}$ water and $25 \mathrm{~mL}$ concentrated sulfuric acid. The mixture was refluxed overnight, and after it cooled, $50 \mathrm{~mL}$ water was added. The usual workup with chloroform afforded $50 \mathrm{mg} \mathrm{(22 \% )}$ of 17 as a white solid: $\mathrm{mp} \mathrm{282-283}$ ${ }^{\circ} \mathrm{C}$; IR $\left(\mathrm{CHCl}_{3}\right) 2940,2860,1730,1700 \mathrm{~cm}^{-1} ;{ }^{1} \mathrm{H} \mathrm{NMR}\left(\mathrm{CDCl}_{3}\right)$ $\delta 3.40(1 \mathrm{H}, \mathrm{m}), 2.76(2 \mathrm{H}, \mathrm{m}), 2.5-1.5(9 \mathrm{H}$, complex $) ;{ }^{13} \mathrm{C} \mathrm{NMR}$ $\left(\mathrm{CDCl}_{3}\right) \delta 207.6\left(\mathrm{C}^{2 / 4}\right), 68.3\left(\mathrm{C}^{3}\right), 45.0\left(\mathrm{C}^{1 / 6}\right), 44.0\left(\mathrm{C}^{10}\right), 38.2\left(\mathrm{C}^{6 / 8}\right)$, $30.0\left(\mathrm{C}^{9}\right), 26.0\left(\mathrm{C}^{7}\right)$; mass spectrum, $m / e$ (relative intensity) 164 $\left(100, \mathrm{M}^{+}\right), 136(14), 79(78)$.

Anal. Calcd for $\mathrm{C}_{10} \mathrm{H}_{12} \mathrm{O}_{2}$ : C, 73.14; $\mathrm{H}, 7.37$. Found: C, 73.08; $\mathrm{H}, 7.54$.

The ${ }^{13} \mathrm{C}$ NMR data of 4-oxa-5-homoadamantane derivatives will be published in a forthcoming paper.

Acknowledgment. We are indebted to Professor Dr. E. Wenkert for helpful discussions. We are also grateful to Dr. D. Müller (Bochum) for recording the mass spectra as well as to Mrs. E. Sauerbier for her skillful assistance in some syntheses. This work was supported by the Fonds der Chemischen Industrie.

Registry No. 1a, 66483-57-6; 1b, 66483-52-1; 1c, 79499-77-7; 6, 78726-35-9; 7, 78726-38-2; 8, 78726-36-0; 9a, 79499-78-8; 9b, 79499$79-9 ; 10,78726-37-1 ; 12 \mathrm{a}, 79499-80-2 ; 17,19214-00-7 ; 19 \mathrm{a}, 79548-72-4$; 19b, 79499-81-3; 19c, 56820-19-0; 21, 18971-91-0; 23, 79499-82-4; 24, 56781-86-3; 25, 56781-85-2; endo-bicyclo[3.3.1]non-6-ene-3-carboxylic acid, 21932-98-9; 2-anti-bromo-4,4-dimethyladamantane, 79499-83-5.

\title{
Vinyl Cations. Comparison of Gas-Phase Thermodynamic and Solvolysis Data with ab Initio MO Calculations
}

\author{
Herbert Mayr,* Reinhard Schneider, Dieter Wilhelm, and P. v. R. Schleyer \\ Institut für Organische Chemie der Friedrich-Alexander-Universität Erlangen-Nürnberg, D-8520 Erlangen, \\ Federal Republic of Germany \\ Received July 1, 1981
}

\begin{abstract}
Ab initio MO calculations with the STO-3G basis set level on cyclic and acyclic methyl- and phenyl-substituted vinyl cations have been used, in combination with the experimental heat of formation of the parent vinyl cation, to evaluate $\Delta H_{f}{ }^{\circ}$ values for a set of vinyl cations. Comparison of these thermodynamic values with solvolysis data shows that only one-quarter of the stabilizing influence of substituents is effective in the solvolysis transition states. The slow solvolysis rates of vinyl compounds are thus not primarily due to the low stability of vinyl cations but to an unusually high kinetic barrier between vinyl derivatives and the corresponding ionic intermediates.
\end{abstract}

A knowledge of relative carbenium ion stabilities is essential for the interpretation of reactions involving carbocations and is being used to help design syntheses via cationic intermediates. ${ }^{1}$ In principle, such relative stabilities may be obtained from solvolysis data or from thermochemical studies. However, only a few gas-phase heats of formation have been determined. Utilization of reactivity data in solution requires that solvolysis transition states resemble the corresponding carbenium ions energetically. Furthermore, published solvolysis rates have been measured under different conditions with varying leaving groups so that a consistent set of data is not available. Therefore, we have now used molecular orbital calculations to gather such thermochemical information.

(1) (a) Mayr, H. Angew. Chem., Int. Ed. Engl. 1981, 20, 184. (b) Mayr, H.; Schütz, F. Tetrahedron Lett. 1981, 925. (c) Mayr, H.; Seitz, B.; Halberstadt-Kausch, I. K. J. Org. Chem. 1981, 46, 1041.
Earlier computational treatments of vinyl cations concentrated on structures and the relative stabilizing abilities of $\alpha$ or $\beta$ substituents. ${ }^{2}$ We now extend this work on polysubstituted and cyclic systems in order to obtain heats of formation of vinyl cations with widely varying substitution patterns $(1-13)$.

Calculations were carried out at the restricted Hartree-Fock level by using the ab initio SCF-MO GAUSSIAN 70 series of programs. ${ }^{3}$ Partial geometry optimizations

(2) (a) Radom, L.; Hariharan, P. C.; Pople, J. A.; Schleyer, P. v. R. J. Am. Chem. Soc. 1973, 95, 6531. (b) Apeloig, Y.; Schleyer, P. v. R.; Pople, J. A. J. Org. Chem. 1977, 42, 3004. (c) Apeloig, Y.; Schleyer, P. v. R.; Pople, J. A. J. Am. Chem. Soc. 1977, 99, 5901. (d) Apeloig, Y.; Collins, J. B.; Cremer, D.; Bally, T.; Haselbach, E.; Pople, J. A.; Chandrasekhar, J.; Schleyer, P. v. R. J. Org. Chem. 1980, 45, 3496. (e) Krishnan, R.; Whiteside, R. A.; Pople, J. A.; Schleyer, P. v. R. J. Am. Chem. Soc. 1981, 103,5649 .

(3) Hehre, W. J.; Lathan, W. A.; Ditchfield, R.; Newton, M. D.; Pople, J. A.; QCPE Program No. 236, Indiana University Bloomington, IN. 
Table I. STO-3G Optimized Structures of Cyclic Vinyl Cations 9-11 in Comparison with 4

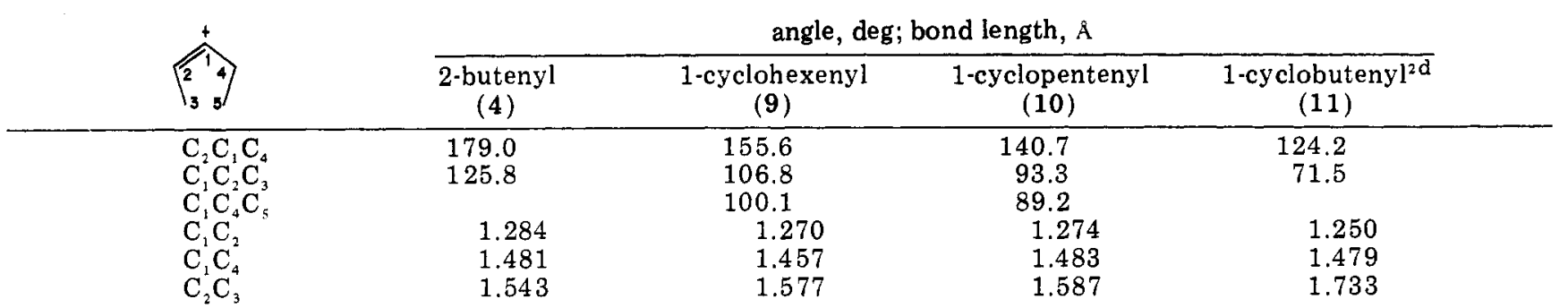

involving the heavy-atom framework and the $\mathrm{CCH}$ angles were performed with the STO-3G minimal basis set ${ }^{4}$ by using analytically calculated gradients. ${ }^{5,6}$ Complete optimizations were carried out for the linear systems with less than five carbon atoms. ${ }^{7}$

\section{Results and Discussion}

Geometry. Acyclic vinyl cations prefer linear arrangements at the positive carbon; for systems in which exact linearity is not allowed by symmetry, deviations of less than $1^{\circ}$ are calculated. The $\mathrm{C}=\mathrm{C}$ bond lengths are practically unaffected by substitution (1.281-1.286 $\AA$ ). This value for 1 is $1.262 \AA$ with the much larger 6-31G* basis. 20

For 7 and 8 , the previously calculated minimum energy conformation with a perpendicular phenyl ring ${ }^{2 \mathrm{~b}}$ was enforced by symmetry constraints. Optimization of the benzene ring of 7 resulted in elongation of the $C_{i}-C_{0}(1.440$ $\AA$ ) and the $\mathrm{C}_{\mathrm{m}}-\mathrm{C}_{\mathrm{p}}$ bonds $(1.407 \AA)$ and in shortening of the $\mathrm{C}_{\mathrm{o}}-\mathrm{C}_{\mathrm{m}}$ bond $(1.372 \AA)$; an energy gain of $2.9 \mathrm{kcal} / \mathrm{mol}$ relative to the partially optimized structure ${ }^{2 b}$ resulted. The benzene ring geometry is closely similar to that calculated for the benzyl cation. ${ }^{8}$

In agreement with findings for the $\beta$-methylvinyl cation $3,{ }^{2 \mathrm{a}}$ the $\beta, \beta$-dimethylvinyl cation 5 prefers the conformation

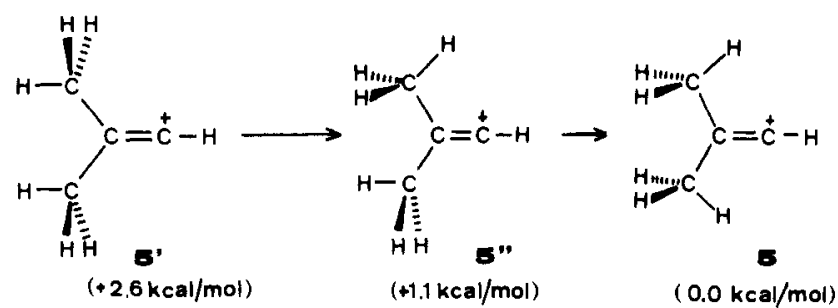

with the cis hydrogens in the plane of the empty $p$ orbital. Consequently, similar conformations were selected for 6 and 8. Eclipsed conformations were chosen for the $\alpha$ methyl groups in 4 and 6 . Such conformations were calculated to be slightly more stable than the perpendicular arrangement in cation $2.2 a$

The geometries of the cyclic vinyl cations 9-11 reflect the tendency of vinyl cations to adopt linear arrangements. Unusually large $\mathrm{C}_{2} \mathrm{C}_{1} \mathrm{C}_{4}$ angles, almost complete flattening of the rings, and decrease of the adjacent $\mathrm{C}_{1} \mathrm{C}_{2} \mathrm{C}_{3}$ and $\mathrm{C}_{1} \mathrm{C}_{4} \mathrm{C}_{5}$ angles result (Table $\mathrm{I}$ ).

In the cyclohexenyl and cyclopentenyl cations, 9 and 10 , the $\mathrm{C}_{1} \mathrm{C}_{2}$ double bond is slightly reduced in length relative to that in 4 whereas $\mathrm{C}_{2} \mathrm{C}_{3}$ is considerably elongated ( +0.04 $\AA$ ) in both cases. These trends continue in the 1-cyclo-

(4) Hehre, W. J.; Ditchfield, R.; Stewart, R. F.; Pople, J. A. J. Chem. Phys. 1969, 51, 2647. 3632 .

(5) Schlegel, H. B.; Wolfe, S.; Bernardi, F. J. Chem. Phys. 1975, 63,

(6) Optimization criterion: $\delta f / \delta x<0.01$ or until the total energy was constant to better than $0.05 \mathrm{kcal} / \mathrm{mol}$.

(7) For the extent of optimization see the footnotes of Table II.

(8) Wolf, J. F.; Harch, R. G.; Taft, R. W.; Hehre, W. J. J. Am. Chem. Soc. 1975, 97, 2902. butenyl cation 11, which is indicated to have a partially opened (bridged) structure. ${ }^{2 \mathrm{~d}}$

Energy. Inherent deficiencies of the computational methods are most efficiently eliminated or reduced by employing isodesmic reactions. Thus, reliable energy differences of various carbenium ions may be obtained from high level ab initio MO calculations. ${ }^{2 e}$ Naturally, this procedure is limited to small systems. However, if the isodesmic reactions considered involve only one class of carbenium ions, even from STO-3G minimal basis set data, reliable energy values can be obtained. Equations 1 and 2 demonstrate the coincidence of calculated and experimental $\Delta E$ values of methyl and phenyl transfer reactions in alkyl cations. ${ }^{9}$

$$
\begin{gathered}
\left(\mathrm{CH}_{3}\right)_{2} \mathrm{CH}^{+}+\mathrm{C}_{2} \mathrm{H}_{6} \rightarrow\left(\mathrm{CH}_{3}\right)_{3} \mathrm{C}^{+}+\mathrm{CH}_{4} \\
\Delta E(\mathrm{STO}-3 \mathrm{G})=-20.2 \mathrm{kcal} / \mathrm{mol}^{11} ; \Delta E(\operatorname{exptl})= \\
-20.7,{ }^{12}-22.0^{13} \mathrm{kcal} / \mathrm{mol} \\
\mathrm{CH}_{3}{ }^{+}+\mathrm{Ph}-\mathrm{CH}_{3} \rightarrow \mathrm{Ph}-\mathrm{CH}_{2}{ }^{+}+\mathrm{CH}_{4} \\
\Delta E(\mathrm{STO}-3 \mathrm{G})=-79.0 \mathrm{kcal} / \mathrm{mol}^{14} ; \Delta E(\mathrm{exptl})= \\
-79.9 \mathrm{kcal} / \mathrm{mol}^{15}
\end{gathered}
$$

In addition, we have reported that there is an excellent agreement between calculated (STO-3G) and experimental $\Delta E$ values for methyl-transfer reactions in the series of methyl substituted allyl cations. ${ }^{10}$ Therefore, we believe the stabilization energies of eq $3-11$, which are based on the total STO-3G energies of Table II, will also be reliable.

$$
\begin{aligned}
& \alpha \text { Substitution } \\
& \mathrm{H}_{2} \mathrm{C}=\mathrm{C}^{+} \mathrm{H}+\mathrm{C}_{2} \mathrm{H}_{6} \rightarrow \mathrm{H}_{2} \mathrm{C}=\mathrm{C}^{+} \mathrm{CH}_{3}+\mathrm{CH}_{4} \\
& \Delta E=-30.3 \mathrm{kcal} / \mathrm{mol}
\end{aligned}
$$

(9) Methyl-transfer reactions involving $\mathrm{C}_{2} \mathrm{H}_{5}{ }^{+}$are not considered in this context because of the problems arising with the nonclassical structure of the ethyl cation (see reference $2 \mathrm{e}$ ).

(10) Mayr, H.; Förner, W.; Schleyer, P. v. R. J. Am. Chem. Soc. 1979, 101,$6032 ; 1980,102,3663$.

(11) Total STO-3G energy for (a) isopropyl cation (-116.02765 au): Radom, L.; Pople, J. A.; Buss, V.; Schleyer, P. v. R. J. Am. Chem. Soc. 1972, 94, 311. (b) For ethane $(-78.30618$ au) and methane $(-39.72686$ au): Lathan, W. A.; Hehre, W. J.; Pople, J. A. J. Am. Chem. Soc. 1971 93, 808. (c) For tert-butyl cation (-154.63918 au): Hehre, W. J. In "Applications of Electronic Structure Theory"; Schaefer, H. F., III, Ed.; Plenum Press: New York, 1977; Vol. III.

(12) $\Delta H_{\mathrm{f}}{ }^{\circ}$ for isopropyl $(192 \mathrm{kcal} / \mathrm{mol})$ and tert-butyl cation (169 kcal/mol): Lossing, F. P.; Semeluk, G. P. Can. J. Chem. 1970, 48, 955.

(13) $\Delta H_{\mathrm{f}}{ }^{\circ}$ for isopropyl $(187.3 \mathrm{kcal} / \mathrm{mol})$ and tert-butyl cation $(162.9$ kcal $/ \mathrm{mol})$ : Houle, F. A.; Beauchamp, J. L. J. Am. Chem. Soc. 1979, 101, 4067 .

(14) Total STO-3G energy for (a) $\mathrm{CH}_{3}{ }^{+}(-38.77948 \mathrm{au})$ and $\mathrm{CH}_{4}$ : ref 11b. (b) For toluene (-266.47382 au): Hehre, W. J.; Radom, L.; Pople, J. A. J. Am. Chem. Soc. 1972, 94, 1496. (c) For $\mathrm{PhCH}_{2}{ }^{+}(-265.65231 \mathrm{au})$ : ref $11 \mathrm{c}$.

(15) $\Delta H_{f}^{\circ}$ for (a) methyl cation $(261 \mathrm{kcal} / \mathrm{mol})$ : ref 12 . (b) For benzyl cation $(211 \mathrm{kcal} / \mathrm{mol})$ : Houle, F. A.; Beauchamp, J. L. J. Am. Chem. Soc. $1978,100,3290$. 


$$
\begin{aligned}
& \mathrm{H}_{2} \mathrm{C}=\mathrm{C}_{1}^{+} \mathrm{H}+\mathrm{Ph}-\mathrm{CH}_{3} \rightarrow \mathrm{H}_{2} \mathrm{C}=\mathrm{C}_{7}^{+} \mathrm{Ph}+\mathrm{CH}_{4} \\
& \Delta E=-65.5 \mathrm{kcal} / \mathrm{mol}(4) \\
& \left(\mathrm{CH}_{3}\right)_{2} \mathrm{C}=\mathrm{C}^{+} \mathrm{H}+\mathrm{C}_{2} \mathrm{H}_{6} \rightarrow\left(\mathrm{CH}_{3}\right)_{2} \mathrm{C}=\mathrm{C}_{6}^{+} \mathrm{CH}_{3}+\mathrm{CH}_{4} \\
& \Delta E=-25.5 \mathrm{kcal} / \mathrm{mol}(5) \\
& \left(\mathrm{CH}_{3}\right)_{2} \mathrm{C}=\mathrm{C}^{+} \mathrm{H}+\mathrm{PhCH}_{3} \rightarrow\left(\mathrm{CH}_{3}\right)_{2} \mathrm{C}=\mathrm{C}^{+} \mathrm{Ph}+\mathrm{CH}_{4} \\
& \Delta E=-51.9 \mathrm{kcal} / \mathrm{mol}(6)
\end{aligned}
$$

Equations 3 and 4 show that the stabilizing effect of phenyl is approximately twice that of methyl. A similar ratio is found in saturated carbenium ions. ${ }^{16}$ From eq 5 and 6 it is evident that the stabilizing effect of $\alpha$ sub-

\section{$\beta$ Substitution}

$$
\begin{aligned}
& \mathrm{H}_{2} \mathrm{C}=\stackrel{+}{\mathrm{C}}-\mathrm{H}+\mathrm{C}_{2} \mathrm{H}_{6} \rightarrow{ }_{4}^{\mathrm{H}_{3} \mathrm{C}}>\mathrm{C}=\stackrel{+}{\mathrm{C}}-\mathrm{H}-\mathrm{CH}_{4} \\
& 1
\end{aligned}
$$

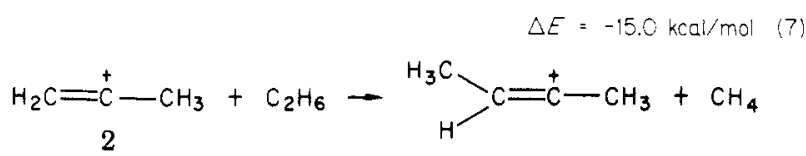

$$
\begin{aligned}
& 4 \\
& \Delta E=-12.3 \mathrm{kcal} / \mathrm{mol}(8) \\
& \mathrm{H}_{2} \mathrm{C}=\stackrel{+}{\mathrm{C}}-\mathrm{H}+2 \mathrm{C}_{2} \mathrm{H}_{6} \rightarrow \underset{\mathrm{H}_{3} \mathrm{C}}{\mathrm{H}}-\stackrel{\mathrm{H}_{3} \mathrm{C}}{\mathrm{C}}=\stackrel{+}{\mathrm{C}}-\mathrm{H}+2 \mathrm{CH}_{4} \\
& 5 \\
& \Delta E=-27.8 \mathrm{kcal} / \mathrm{mol}(9) \\
& \mathrm{H}_{2} \mathrm{C}=\stackrel{+}{\mathrm{C}}-\mathrm{CH}_{3}+2 \mathrm{C}_{2} \mathrm{H}_{6} \rightarrow \underset{\mathrm{H}_{3} \mathrm{C}}{\mathrm{H}_{3} \mathrm{C}} \mathrm{C}=\stackrel{+}{\mathrm{C}}-\mathrm{CH}_{3}+2 \mathrm{CH}_{4} \\
& 6 \\
& \Delta E=-23.1 \mathrm{kcal} / \mathrm{mol}(10) \\
& \mathrm{H}_{2} \mathrm{C}=\stackrel{+}{\mathrm{C}}-\mathrm{Ph}+2 \mathrm{C}_{2} \mathrm{H}_{6} \rightarrow \underset{\mathrm{H}_{3} \mathrm{C}}{\mathrm{H}_{3} \mathrm{C}}-\mathrm{C}=\stackrel{+}{\mathrm{C}}-\mathrm{Ph}+\mathrm{CH}_{4} \\
& 8 \\
& \Delta E=-17.2 \mathrm{kcal} / \mathrm{mol}
\end{aligned}
$$

stituents is somewhat reduced if the $\beta$-carbon is methyl substituted. Methyl groups at the $\beta$-carbon stabilize vinyl cations by 15 (eq 7) and $12 \mathrm{kcal} / \mathrm{mol}$ (eq 8), though this position is formally uncharged. This effect has been attributed to hyperconjugation..$^{2 c}$ As expected, the $\beta$-methylation effect decreases the more the positive charge is stabilized by $\alpha$ substituents (eq 9-11).

Cyclic Vinyl Cations. ${ }^{18}$ Cyclic vinyl cations are less stable than the acyclic analogues. According to eq 12 and 13, 1-cyclohexenyl and 1-cyclopentenyl cations are destabilized by 17 and $27 \mathrm{kcal} / \mathrm{mol}$ relative to their acyclic counterpart, 4. With a $\mathrm{C}=\mathrm{C}^{+}-\mathrm{C}$ angle of $155^{\circ}$, the 1 cyclohexenyl cation is not very different from acyclic species. Therefore, eq 12 can be expected to give a reliable $\Delta E$ value for the reasons discussed above. In the isodesmic reactions, 13 and 14, carbenium ions of widely different structures are correlated, however, and we cannot be sure that the calculated numbers are accurate. This fact is

(16) Streitwieser, A., Jr, "Solvolytic Displacement Reactions"; McGraw-Hill: New York, 1962; pp 42, 43.

(17) Since the phenyl ring of $\mathbf{8}$ is not optimized, the total energy $(-303.01200 \mathrm{au})$ of partially optimized $7^{2 \mathrm{~b}}$ was used for this equation.

(18) Total STO-3G energies of (a) cyclohexene $(-230.26065$ au) and cyclopentene $(-191.67362$ au): complete optimization except $\mathrm{CH}$ bond lengths. (b) For cyclobutene (-153.04028 au) and cis-butene $(-154.24109$ au): Hehre, W. J.; Pople J. A. J. Am. Chem. Soc. 1975, 97, 6941.

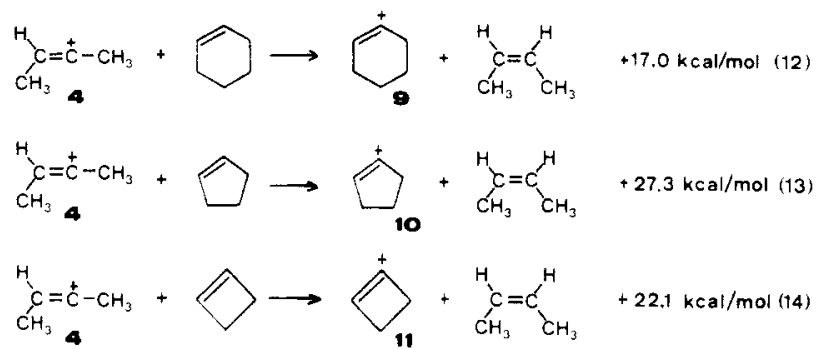

stressed by the finding that the isodesmic reaction comparing 2 and 11 displays considerable basis set dependence. ${ }^{2 \mathrm{~d}}$ Eqs 16 and 17 show that methylation of the $\beta$-carbon has approximately the same effect in cyclic vinyl cations as in acyclic species (eq 15).

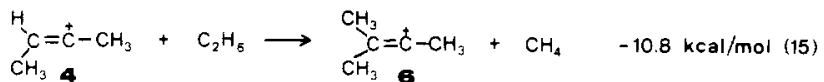

$$
\begin{aligned}
& \bigodot_{0}^{+}+\mathrm{C}_{2} \mathrm{H}_{8} \longrightarrow{ }^{\mathrm{H}_{3} \mathrm{C}}+\mathrm{CH}_{4}-11.2 \mathrm{kcal} / \mathrm{mol}(16) \\
& \bigcup_{10}^{+}+\mathrm{C}_{2} \mathrm{H}_{6} \rightarrow{ }^{\mathrm{H}_{3} \mathrm{C}}+\mathrm{CH}_{13}-12.7 \mathrm{kcal} / \mathrm{mol}(17)
\end{aligned}
$$

Heats of Formation. The calculated $\Delta E$ values of eq 3-17 may be used to evaluate heats of formation of vinyl cations $2-13$ on the basis of the experimental $\Delta H_{\mathrm{f}}{ }^{\circ}$ values of the neutral hydrocarbons ${ }^{19}$ and of the unsubstituted vinyl cation 1.20 Comparison of the resulting calculated $\Delta H_{f}^{\circ}$ values (Table II) with the few available experimental data (in kilocalories/mole; see below) show satisfactory agreement. Our assumptions are verified.

$$
\begin{array}{lcl} 
& \Delta H_{\mathrm{f}}^{\circ} \text { (calcd) } & \Delta H_{\mathrm{f}}^{\circ} \text { (exptl) } \\
\mathrm{H}_{2} \mathrm{C}=\mathrm{C}^{+} \mathrm{CH}_{3} & 233 & 230^{20}, 237^{21} \\
\mathrm{CH}_{3} \mathrm{CH}=\mathrm{C}^{+} \mathrm{CH}_{3} & 218 & 215^{20}, 218^{22} \\
\left(\mathrm{CH}_{3}\right)_{2} \mathrm{C}=\mathrm{C}^{+} \mathrm{CH}_{3} & 205 & 202^{22}
\end{array}
$$

Comparison with Solvolysis Data. On the basis of the Hammond-Leffler postulate, ${ }^{23}$ one can expect a linear correlation between activation free enthalpies of solvolysis reactions $\left(\Delta G^{\ddagger}\right)$ and the dissociation free enthalpies $(\Delta G)$. If no specific solvation effects exist, the $\Delta G^{*}$ (solvolysis) values should also be related to the gas-phase stabilities of the corresponding vinyl cations (Table III).

Figure 1 shows the linear correlation between the solvolysis free enthalpies of vinyl triflates and the heat of

(19) Cox, J. D.; Pilcher, G. "Thermochemistry of Organic and Organometallic Compounds"; Academic Press: New York, 1970.

(20) Aue, D. H.; Bowers, M. T. In "Gas Phase Ion Chemistry"; Bowers,

M. T., Ed.; Academic Press: New York, 1979; Vol. 2, Chapter 9.

(21) Aue, D. H.; Davidson, W. R.; Bowers, M. T. J. Am. Chem. Soc. $1976,98,6700$.

(22) Stang, P. J.; Rappoport, Z.; Hanack, M.; Subramanian, L. R. "Vinyl Cations"; Academic Press: New York, 1979; p 7.

(23) Leffler, J. E.; Grunwald, E. "Rates and Equilibria of Organic Reactions"; Wiley: New York, 1963; pp 156, 163.

(24) Summerville, R. H.; Senkler, C. A.; Schleyer, P. v. R.; Dueber, T. E.; Stang, P. J. J. Am. Chem. Soc. 1974, 96, 1100.

(25) Pfeifer, W. D.; Bahn, C. A.; Schleyer, P. v. R.; Bocher, S.; Harding, C. E.; Hummel, K.; Hanack, M.; Stang, P. J. J. Am. Chem. Soc. 1971, 93 1513.

(26) Hanack, M.; Schleyer, P. v. R.; Martinez, A. G. An. Quim. 1974, 70,941 .

(27) Benson, S. W. "Thermochemical Kinetics", 2nd Ed.; Wiley-Interscience: New York, 1976.

(28) Stang, P. J.; Hargrove, R. J.; Dueber, T. E. J. Chem. Soc., Perkin Trans. 21977,1486

(29) Hargrove, R. J.; Dueber, T. E.; Stang, P. J. J. Chem. Soc., Chem. Commun. 1970, 1614.

(30) (a) Grob, C. A.; Cseh, G. Helv. Chim. Acta 1964, 47, 194. (b) Derocque, J.-L; Sundermann, F.-B.; Youssif, N.; Hanack, M. Justus Liebigs Ann. Chem. 1973, 419.

(31) Hanack, M.; Bentz, H.; Märkl, R.; Subramanian, L. R. Justus Liebigs Ann. Chem. 1978, 1894. 
Table II. Total Energies (au, STO-3G) of Vinyl Cations and Calculated Heats of Formation (kcal/mol)

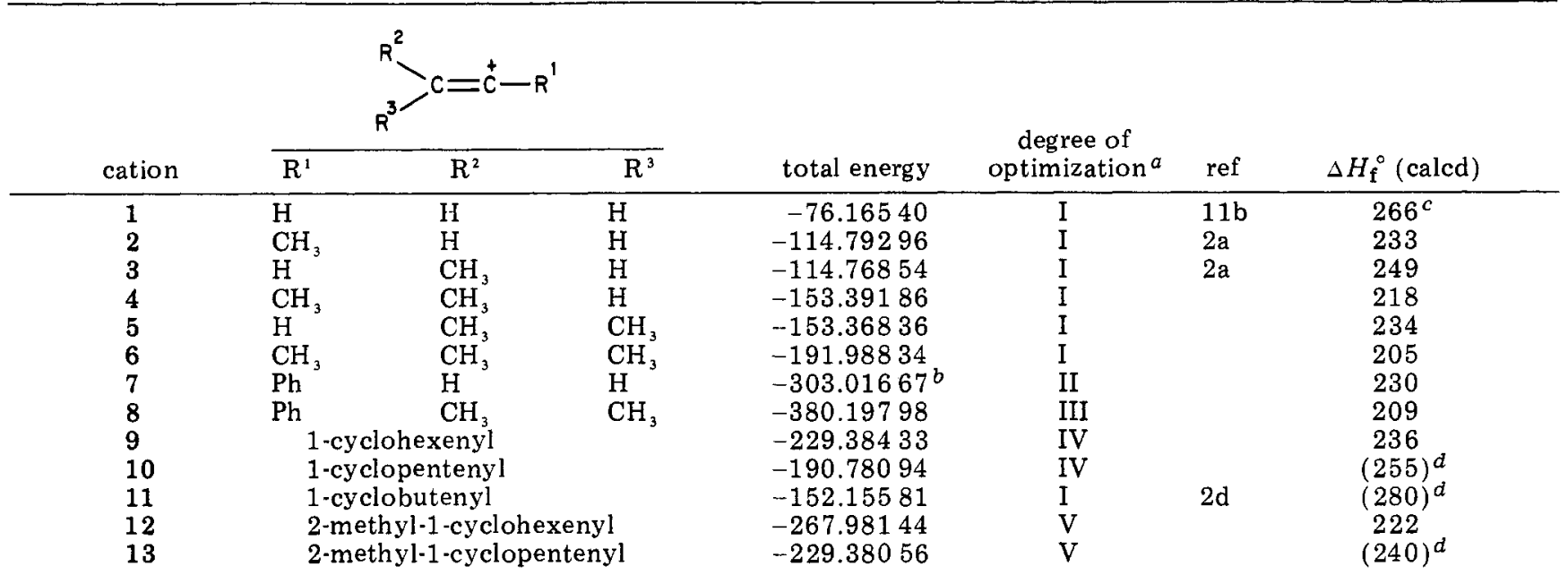

${ }^{a} \mathrm{I}=$ complete optimization; $\mathrm{II}=$ heavy-atom framework fully optimized; $\mathrm{III}=\left(\mathrm{CH}_{3}\right)_{2} \mathrm{C}=\mathrm{C}^{+}$fragment as calculated for 6 , with phenyl as reported in ref $2 \mathrm{~d} ; \mathrm{IV}=$ complete optimization except for $\mathrm{C}-\mathrm{H}$ bond lengths; $\mathrm{V}=$ geometries of 9 and 10 , respective, methyl groups with standard geometry. ${ }^{b}$ Complete optimization in $C_{2 v}$ symmetry except for aromatic $\mathrm{C}-\mathrm{H}$ results in an energy gain of $2.9 \mathrm{kcal} / \mathrm{mol}$ relative to the structure with phenyl in standard geometry. ${ }^{2 \mathrm{~b}} \mathrm{c}^{\mathrm{C}}$ Experimental reference value. $d$ Uncertain; see text.

Table III. Solvolysis Rates of Vinyl Triflates in $50 \%$ Ethanol- $\mathrm{H}_{2} \mathrm{O}$ at $75^{\circ} \mathrm{C}$

\begin{tabular}{|c|c|c|c|c|c|c|}
\hline \multirow[b]{2}{*}{$\mathrm{R}-\mathrm{OTf}$} & \multicolumn{3}{|c|}{ solvolyses } & \multirow[b]{2}{*}{$\Delta H_{\mathrm{f}}^{\circ}$ (ion) } & \multirow{2}{*}{$\begin{array}{c}\Delta H_{\mathrm{f}}^{\circ} \\
\text { (precursor) }^{a}\end{array}$} & \multirow[b]{2}{*}{$\Delta H^{f}$} \\
\hline & $k_{1}, \mathrm{~s}^{-1}$ & $\Delta G^{\ddagger}, \mathrm{kcal} / \mathrm{mol}$ & ref & & & \\
\hline & $3.3 \times 10^{-4}$ & 26.0 & 24 & 233 & -34.3 & 267 \\
\hline & $1.75 \times 10^{-4}$ & 26.4 & 24 & 218 & -41.2 & 259 \\
\hline & $2.94 \times 10^{-4}$ & 26.0 & 24 & 205 & -49.7 & 255 \\
\hline & $2.74 \times 10^{-1}$ & 21.3 & $b$ & 230 & -3.6 & 234 \\
\hline & 1.68 & 20.0 & $c$ & 209 & -18.9 & 228 \\
\hline & & 32.6 & 25 & 236 & -39.8 & 276 \\
\hline & & $>35.5$ & $25, d$ & $(255)$ & -30.4 & $(285)$ \\
\hline & & 27.0 & $e$ & $(280)$ & -1.5 & $(282)$ \\
\hline & & 30.8 & 25 & 222 & -48.2 & 270 \\
\hline & & $>31.3$ & $26, d$ & $(240)$ & -38.8 & $(279)$ \\
\hline
\end{tabular}

${ }^{a}$ Calculated from group increments; ${ }^{27}$ since the absolute value is not of interest, OTf has been replaced by $\mathrm{OCH}_{3}$ for simplicity. " $b$ rom $k_{1}\left(80 \%\right.$ ethanol) ${ }^{28}$ by using the " $m Y$ equation" (ref 38 ), $m=0.568$ from ref 29 . "From rate ratio $\left(\mathrm{CH}_{3}\right)_{2} \mathrm{C}=\mathrm{C}(\mathrm{Br}) \mathrm{Ph} / \mathrm{H}_{2} \mathrm{C}=\mathrm{C}(\mathrm{Br}) \mathrm{Ph}$ at $120^{\circ} \mathrm{C} .^{30}{ }^{d}$ Since solvolysis has been shown to proceed via $\mathrm{S}-\mathrm{O}$ cleavage ${ }^{31}$ this value represents a lower limit. e From relative rates of 1 -cyclobutenyl and 1 -cyclohexenyl nonaflates $($ see ref $22, \mathrm{p} 242)$. $f \Delta H=$ $\Delta H_{f}^{\circ}$ (ion) $-\Delta H_{\mathrm{f}}^{\circ}$ (precursor) (ref 38 ).

formation differences between the cations and the precursors. However, two points deviate, those for 2-propenyl and for 1-cyclobutenyl triflates. Since the deviation of cyclobutenyl triflate can be attributed to the inadequacy of our computational approach (see discussion above), 11 has been omitted from the graph. On the other hand, the displacement of 2-propenyl triflate must have a physical meaning; the calculated heat of formation of vinyl cation 2 is in agreement with the experimental gas-phase value. The finding that 2-propenyl triflate solvolyses faster than expected from the gas-phase stability of cation 2 supports a previous suggestion that systems with $\beta$-hydrogens trans to the leaving group experience specific solvation effects in the solvolysis transition states. ${ }^{24}$ To eliminate this effect in 4, the solvolysis data of $(E)-2$-buten-2-yl triflate and not of its $Z$ isomer has been included to the plot.

From the correlation line one can expect activation free enthalpies for the formation of cyclopentenyl cations which are not very different from those observed for $\mathrm{O}-\mathrm{S}$ cleavage in 1-cyclopentenyl triflates. ${ }^{31,32}$ Probably, O-S cleavage is only slightly favored over the formation of vinyl cations. This assumption is supported by a recent report that 1 cyclopentenyl cations are formed readily via $\pi$ cyclization. ${ }^{1 \mathrm{c}}$

(32) This conclusion is based on the assumption that STO-3G calculations are still appropriate for 1-cyclopentenyl cations. 


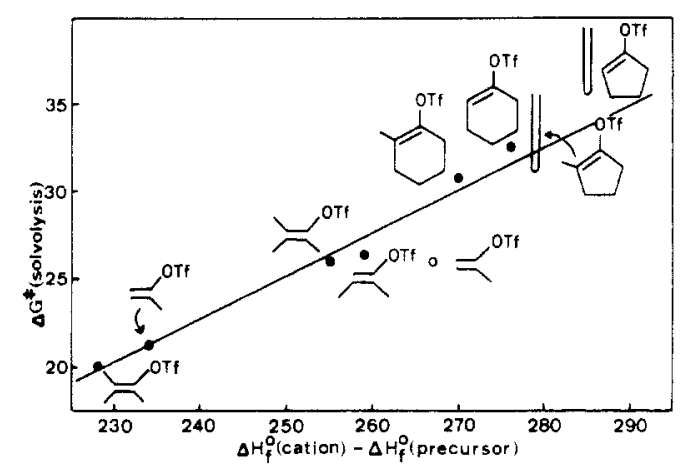

Figure 1. Correlation between activation free enthalpies of solvolysis reactions of vinyl triflates and gas-phase stabilities of vinyl cations.

If the questionable data for 2-propenyl triflate and 1cyclobutenyl triflate are omitted, regression analysis yields a linear correlation $\left(r^{2}=0.980\right)$ with a slope of 0.26 . This shows that only a small fraction of carbenium ion character is developed in the solvolysis transition states. Corresponding plots for solvolyses of allylic chlorides in formic acid and of tertiary alkyl chlorides in ethanol gave slopes of $0.51^{10}$ and $0.66,{ }^{33}$ respectively, indicating a higher cationic character in these transition states.

\section{Conclusions}

The slow solvolysis rates of vinylic compounds have been considered to indicate low stability of vinyl cations. This interpretation may be erroneous, however, since eq 18

$\mathrm{Ph}-\mathrm{C}^{+}=\mathrm{CH}_{2}+\left(\mathrm{CH}_{3}\right)_{3} \mathrm{CH} \rightarrow$

$230 \mathrm{kcal} / \mathrm{mol}-32.4 \mathrm{kcal} / \mathrm{mol}$

$$
\begin{aligned}
& \mathrm{Ph}-\mathrm{CH}=\mathrm{CH}_{2}+\left(\mathrm{CH}_{3}\right)_{3} \mathrm{C}^{+} \quad \Delta H=+1 \mathrm{kcal} / \mathrm{mol}^{35} \\
& 35.3 \mathrm{kcal} / \mathrm{mol} \quad 163 \mathrm{kcal} / \mathrm{mol}
\end{aligned}
$$

(33) Schleyer, P. v. R.; Mayr, H., unpublished shows that tert-butyl and $\alpha$-phenylvinyl cations have similar hydride affinities (i.e., similar thermodynamic stabilities) though tert-butyl bromide ${ }^{34}$ solvolyses ten powers of ten faster than $\alpha$-bromostyrene. ${ }^{30 a}$ Instead, the transition states for vinyl solvolyses reflect the energies of the fully developed ions to a much smaller extent than do the transition states in alkyl solvolyses. Thus, vinyl cations are formed much more slowly than trivalent carbenium ions of equal thermodynamic stability. This point is illustrated nicely by the fact that progargyl bromide $\mathbf{1 4}$

$$
\mathrm{HC} \equiv \mathrm{CCH}_{2} \mathrm{Br} \rightarrow \mathrm{HC} \ddot{\circ} \stackrel{+}{\mathrm{C}}-\mathrm{CH}_{2} \leftarrow \mathrm{BrCH}=\mathrm{C}=\mathrm{CH}_{2}
$$

14

15

solvolyses 4000 times faster than allenyl bromide 15 though both give the same carbenium ion. ${ }^{36}$ Ground-state effects cannot be responsible since 14 and 15 have similar thermodynamic stabilities. ${ }^{37}$ We suspect that the transition states for vinyl solvolyses are less effectively solvated even when solvent "ionizing power" rather than solvent nucleophilicity is involved. Alternatively, there may be a larger barrier in going from a $\mathrm{sp}^{2}$ ground state to an $\mathrm{sp}$ ion pair transition state than that for a corresponding $\mathrm{sp}^{3}-\mathrm{sp}^{2}$ change.

Acknowledgment. We thank the Deutsche Forschungsgemeinschaft and the Fonds der Chemischen Industrie for financial support and the staff of the Regionales Rechenzentrum Erlangen for their cooperation.

Registry No. 1, 14604-48-9; 2, 50457-57-3; 3, 50457-58-4; 4 , 79449-26-6; 5, 79449-27-7; 6, 79449-28-8; 7, 62698-27-5; 8, 56126-11-5; $9,60690-49-5 ; 10,60690-50-8 ; 12,79449-29-9 ; 13,79449-30-2$

(34) Fainberg, A. H.; Winstein, S. J. Am. Chem. Soc. 1957, 79, 1602.

(35) For $\Delta H^{\circ}\left(t-\mathrm{Bu}^{+}\right)=163 \mathrm{kcal} / \mathrm{mol}^{13}$ if $\Delta H_{\mathrm{f}}^{\circ}\left(t-\mathrm{Bu}^{+}\right)$is taken to be $169 \mathrm{kcal} / \mathrm{mol},{ }^{12} \Delta H($ eq 18$)=7 \mathrm{kcal} / \mathrm{mol}$.

(36) Lee, C. V.; Hargrove, R. J.; Dueber, T. E.; Stang, P. J. Tetrahedron Lett. 1971, 2519.

(37) Equilibrium mixture contains $35 \% 14$ and $65 \% 15$ : Jacobs, $T$. L.; Brill, W. F. J. Am. Chem. Soc. 1953, 75, 1314.

(38) Grunwald, E.; Winstein, S. J. Am. Chem. Soc. 1948, 70, 846.

\title{
Active Metals from Potassium-Graphite. ${ }^{1}$ Highly Dispersed Nickel on Graphite as a New Catalyst for the Stereospecific Semihydrogenation of Alkynes
}

\author{
Diego Savoia, Emilio Tagliavini, Claudio Trombini, and Achille Umani-Ronchi* \\ Istituto Chimico "G. Ciamician", Università di Bologna, 40126 Bologna, Italy
}

Received July 3, 1981

\begin{abstract}
The reduction of $\mathrm{NiBr}_{2} \cdot 2 \mathrm{DME}$ by means of potassium-graphite affords highly dispersed nickel on the graphite surface (Ni-Gr1). Freshly prepared Ni-Gr1 is used "in situ" as a catalyst for semihydrogenation of alkynes to alkenes in the presence of ethylenediamine as catalyst modifier. Unconjugated and conjugated $(Z)$-alkenes with a stereospecificity of $96-99 \%$ and $94 \%$, respectively, are obtained.
\end{abstract}

Alkynes are unreplaceable tools in organic chemistry for the facile construction of carbon-carbon bonds through acetylides and for the reduction to $(E)$ - or $(Z)$-alkenes by a variety of stereospecific methods.

(1) Previous works on the use of potassium-graphite in organic synthesis: Savoia, D.; Trombini, C.; Umani-Ronchi, A. J. Chem. Soc., Perkin Trans. 1 1977, 123; Tetrahedron Lett. 1977, 653; J. Org. Chem. 1978, 43, 2907. Contento, M.; Savoia, D.; Trombini, C.; Umani-Ronchi, A. Synthesis 1979, 30 .
Heterogeneous catalytic hydrogenation is a topic in organic synthesis, ${ }^{2}$ especially in the field of natural products, since it allows alkynes to be used as masked $(Z)$-alkenes. $^{3}$ For this purpose the most widely used catalysts consist in palladium dispersed on suitable supports, the Lindlar catalyst affording the best stereospecificity, since

(2) Rylander, P. N. "Catalytic Hydrogenation in Organic Synthesis"; Academic Press: New York, 1979; Chapter 2.

(3) Henrick, C. A. Tetrahedron 1977, 33, 1845. 